\title{
The X-linked Blood Group System Xg Tests on Unrelated People and Families of Northern European Ancestry
}

\author{
RUTH SANGER, PATRICIA TIPPETT, and JUNE GAVIN
}

\author{
From the MRC Blood Group Unit, The Lister Institute, Chelsea Bridge Road, London SW1W $8 R H$
}

The X-linked blood group system $\mathrm{Xg}$ was recognized in November 1961 (Mann et al, 1962). An account up to 14 July 1965 of its incidence and inheritance in people of northern European extraction tested in the Unit was published in this Journal by Noades et al (1966). This present paper brings our account up to 23 December 1969.

The red cell samples came from four main sources: (1) members of laboratory staffs and volunteer donors tested to set a net in which other examples of anti- $\mathrm{Xg}^{\mathrm{a}}$ might be caught; (2) normal families; (3) very many families with $\mathrm{X}$-linked dimorphisms tested for X-mapping purposes; (4) the parents of children with an abnormality of number or of form of the $\mathrm{X}$ chromosome (which parents have a normal distribution of the $\mathrm{Xg}$ groups).

\section{Unrelated People}

The results of testing 6784 unrelated people are in Table I. The gene frequencies for the total are $X g^{a} 0.659$ and $X g 0.341$, by chance exactly the same as they were at the 3418 level (Noades et al 1966).

The gene frequencies were calculated by the formula devised by Haldane (1963) for the purpose: frequency of gene $X g=$

$$
\frac{\left[4(2 \mathrm{f}+\mathrm{m})(\mathrm{b}+2 \mathrm{~d})+\mathrm{a}^{2}\right]^{1 / 2}-\mathrm{a}}{2(2 \mathrm{f}+\mathrm{m})}
$$

frequency of gene $X g^{\mathrm{a}}=1-$ frequency of $X g$ where the letters represent the absolute numbers observed in the following categories:

\begin{tabular}{lccc}
\hline & $\mathrm{Xg}(\mathrm{a}+)$ & $\mathrm{Xg}(\mathrm{a}-)$ & Total \\
\hline Males & $\mathrm{a}$ & $\mathrm{b}$ & $\mathrm{m}$ \\
Females & $\mathrm{c}$ & $\mathrm{d}$ & $\mathrm{f}$ \\
\hline
\end{tabular}

The gene frequencies thus calculated from the male and female absolute numbers can be recombined to give the expected genotype and pheno-

\footnotetext{
Received 12 April 1971.
}

type frequencies. For example, the expected frequencies for the total people of northern European extraction are:

\begin{tabular}{|c|c|}
\hline Males & Females \\
\hline $\begin{array}{cc}X g^{\mathrm{a}} & 0.659 \\
X g & 0.341\end{array}$ & $\left.\begin{array}{ll}X g^{\mathrm{a}} X g^{\mathrm{a}} & 0.434 \\
X g^{\mathrm{a}} X g & 0.450 \\
X g X g & 0.116\end{array}\right\} 0.884$ \\
\hline
\end{tabular}

Such calculated genotype frequencies can be reapplied to the people from whom they were derived to see whether the observed male and female distributions of the $\mathrm{Xg}$ phenotypes are mutually concordant. The results of these tests are expressed in terms of $\chi^{2}$ (for one degree of freedom) in the last two columns of Table I. There is serious disharmony in only one set of people: the disturbance in the Finns is highly significant. Here, we guess we are entangled in some complication of ascertainment resulting from the collecting, for other purposes, of certain samples from small Finnish isolates, which no doubt contain much hidden consanguinity.

The figures for the 4 main divisions are summed at the bottom of Table I and are compared each to each in Table II. An excess of $\mathrm{Xg}\left(\mathrm{a}_{-}\right)$females in the Scandinavian sample, mainly contributed by the Danes, is certainly significant, but of what we cannot say. It could perhaps reflect a real difference in gene frequency in these people, for the excess of the allele $X g$ in females is exactly matched in the Scandinavian males.

Besides progressive publications from this Unit, summed in the present paper, substantial series of tests on unrelated people of northern European origin have been reported: 588 Canadians (Chown, Lewis, and Kaita, 1964), 1382 American whites (Dewey and Mann, 1967), and 558 Swiss (Metaxas and Metaxas-Bühler, 1970). All the frequencies are in good agreement. 
TABLE I

Xg GROUPS OF 6784 PEOPLE OF NORTHERN EUROPEAN EXTRACTION NOT KNOWN TO BE RELATED

\begin{tabular}{|c|c|c|c|c|c|c|c|c|c|c|c|c|c|}
\hline \multirow{2}{*}{\multicolumn{2}{|c|}{$\begin{array}{l}\text { Samples Posted } \\
\text { From }\end{array}$}} & \multicolumn{4}{|c|}{ Males } & \multicolumn{4}{|c|}{ Females } & \multicolumn{2}{|c|}{ Gene Frequency } & \multicolumn{2}{|c|}{$x_{1}^{2}$ (see text) } \\
\hline & & \multirow{2}{*}{$\begin{array}{c}\text { Total } \\
1665 \\
160\end{array}$} & \multirow{2}{*}{ 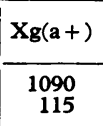 } & \multirow{2}{*}{$\begin{array}{c}\mathrm{Xg}(\mathrm{a}-) \\
\begin{array}{r}575 \\
45\end{array}\end{array}$} & \multirow{2}{*}{\begin{tabular}{|c|}
$\begin{array}{c}\text { Proportion } \\
\text { Xg(a }-)\end{array}$ \\
0.345 \\
0.281 \\
\end{tabular}} & \multirow{2}{*}{$\begin{array}{r}\text { Total } \\
\begin{array}{r}1743 \\
193\end{array}\end{array}$} & \multirow{2}{*}{$\begin{array}{r}\mathrm{Xg}(\mathrm{a}+) \\
1569 \\
179\end{array}$} & \multirow{2}{*}{$\begin{array}{c}\mathrm{Xg}(\mathrm{a}-) \\
\begin{array}{c}174 \\
14\end{array}\end{array}$} & \multirow{2}{*}{$\begin{array}{c}\begin{array}{c}\text { Proportion } \\
\mathbf{X g}(\mathrm{a}-)\end{array} \\
0.100 \\
0.073\end{array}$} & \multirow{2}{*}{$\begin{array}{l}X g^{\mathrm{a}} \\
0.669 \\
0.725\end{array}$} & \multirow{2}{*}{$\begin{array}{c}X g \\
0 \cdot 331 \\
0 \cdot 275\end{array}$} & \multirow{2}{*}{$\begin{array}{l}\text { Males } \\
1.66 \\
0.03\end{array}$} & \multirow{2}{*}{$\begin{array}{c}\text { Females } \\
\begin{array}{l}1.61 \\
0.03\end{array}\end{array}$} \\
\hline $\begin{array}{l}\text { England } \\
\text { Scotland }\end{array}$ & $\begin{array}{r}3408 \\
353\end{array}$ & & & & & & & & & & & & \\
\hline $\begin{array}{l}\text { USA } \\
\text { Canada }\end{array}$ & $\begin{array}{r}941 \\
72\end{array}$ & $\begin{array}{r}627 \\
34\end{array}$ & $\begin{array}{r}414 \\
24\end{array}$ & $\begin{array}{r}213 \\
10\end{array}$ & $\begin{array}{l}0.340 \\
0.294\end{array}$ & $\begin{array}{r}314 \\
38\end{array}$ & $\begin{array}{r}276 \\
33\end{array}$ & $\begin{array}{r}38 \\
5\end{array}$ & $\begin{array}{l}0 \cdot 121 \\
0 \cdot 132\end{array}$ & $\begin{array}{l}0.658 \\
0.669\end{array}$ & $\begin{array}{l}0.342 \\
0.331\end{array}$ & $\begin{array}{l}0.02 \\
0.14\end{array}$ & $\begin{array}{l}0.04 \\
0 \cdot 19\end{array}$ \\
\hline $\begin{array}{l}\text { Finland } \\
\text { Sweden } \\
\text { Denmark } \\
\text { Norway } \\
\text { Iceland }\end{array}$ & $\begin{array}{r}357 \\
279 \\
286 \\
31 \\
3\end{array}$ & $\begin{array}{r}188 \\
137 \\
137 \\
21 \\
1\end{array}$ & $\begin{array}{r}132 \\
84 \\
85 \\
13 \\
1\end{array}$ & $\begin{array}{r}56 \\
53 \\
52 \\
8 \\
0\end{array}$ & $\begin{array}{l}0.298 \\
0.387 \\
0.380\end{array}$ & $\begin{array}{r}169 \\
142 \\
149 \\
10 \\
2\end{array}$ & $\begin{array}{r}130 \\
125 \\
120 \\
10 \\
2\end{array}$ & $\begin{array}{r}39 \\
17 \\
29 \\
0 \\
0\end{array}$ & $\begin{array}{l}0.231 \\
0 \cdot 120 \\
0 \cdot 195\end{array}$ & $\begin{array}{l}0.605 \\
0.634 \\
0.585\end{array}$ & $\begin{array}{l}0.395 \\
0.366 \\
0.415\end{array}$ & $\begin{array}{l}7.36 \\
0 \cdot 27 \\
0.69\end{array}$ & $\begin{array}{l}7.25 \\
0.24 \\
0.54\end{array}$ \\
\hline $\begin{array}{l}\text { France } \\
\text { Netherlands } \\
\text { N. Italy } \\
\text { Switzerland }\end{array}$ & $\begin{array}{r}264 \\
188 \\
61 \\
51\end{array}$ & $\begin{array}{r}140 \\
116 \\
29 \\
23\end{array}$ & $\begin{array}{l}79 \\
86 \\
15 \\
15\end{array}$ & $\begin{array}{r}61 \\
30 \\
14 \\
8\end{array}$ & $\begin{array}{l}0.436 \\
0.259 \\
0.483\end{array}$ & $\begin{array}{r}124 \\
72 \\
32 \\
28\end{array}$ & $\begin{array}{r}110 \\
63 \\
30 \\
22\end{array}$ & $\begin{array}{r}14 \\
9 \\
2 \\
6\end{array}$ & $\begin{array}{l}0.113 \\
0.125 \\
0.063\end{array}$ & $\begin{array}{l}0.612 \\
0.705 \\
0.633\end{array}$ & $\begin{array}{l}0.388 \\
0.295 \\
0.367\end{array}$ & $\begin{array}{l}1.35 \\
0.74 \\
1.69\end{array}$ & $\begin{array}{l}1.37 \\
1.31 \\
1 \cdot 42\end{array}$ \\
\hline $\begin{array}{l}\text { N. Spain } \\
\text { Poland } \\
\text { Germany } \\
\text { Belgium } \\
\end{array}$ & $\begin{array}{r}64 \\
173 \\
164 \\
89\end{array}$ & $\begin{array}{l}27 \\
87 \\
81 \\
40\end{array}$ & $\begin{array}{l}18 \\
56 \\
53 \\
24\end{array}$ & $\begin{array}{r}9 \\
31 \\
28 \\
16 \\
\end{array}$ & $\begin{array}{l}0.333 \\
0.356 \\
0.346 \\
0.400 \\
\end{array}$ & $\begin{array}{l}37 \\
86 \\
83 \\
49 \\
\end{array}$ & $\begin{array}{l}33 \\
78 \\
75 \\
45 \\
\end{array}$ & $\begin{array}{l}4 \\
\mathbf{4} \\
8 \\
4 \\
4 \\
\end{array}$ & $\begin{array}{l}0.108 \\
0.093 \\
0.096 \\
0.082 \\
\end{array}$ & $\begin{array}{l}0.669 \\
0.669 \\
0.672 \\
0.661 \\
\end{array}$ & $\begin{array}{l}0.331 \\
0.331 \\
0.328 \\
0.339 \\
\end{array}$ & $\begin{array}{l}0.08 \\
0.24 \\
0.11 \\
0.66\end{array}$ & $\begin{array}{l}0.04 \\
0.25 \\
0.11 \\
0.54\end{array}$ \\
\hline Total & 6784 & 3513 & 2304 & 1209 & 0.344 & 3271 & 2900 & 371 & $0 \cdot 133$ & 0.659 & 0.341 & 0.20 & 0.21 \\
\hline $\begin{array}{l}\text { Britain } \\
\text { N. America } \\
\text { Scandinavia } \\
\quad \text { (excluding }\end{array}$ & $\begin{array}{l}3761 \\
1013\end{array}$ & $\begin{array}{r}825 \\
661\end{array}$ & $\begin{array}{r}1205 \\
438\end{array}$ & $\begin{array}{l}620 \\
223\end{array}$ & $\begin{array}{l}0.340 \\
0.337\end{array}$ & $\begin{array}{r}1936 \\
352\end{array}$ & $\begin{array}{r}1748 \\
309\end{array}$ & $\begin{array}{r}188 \\
43\end{array}$ & $\begin{array}{l}0.097 \\
0.122\end{array}$ & $\begin{array}{l}0.674 \\
0.658\end{array}$ & $\begin{array}{l}0.326 \\
0.342\end{array}$ & $\begin{array}{l}1.68 \\
0.05\end{array}$ & $\begin{array}{l}1.58 \\
0.10\end{array}$ \\
\hline $\begin{array}{l}\text { Finland) } \\
\text { Mainland of }\end{array}$ & 559 & 296 & 183 & 113 & 0.382 & 303 & 257 & 46 & $0 \cdot 152$ & 0.614 & 0.386 & 0.02 & 0.02 \\
\hline Europe & 1054 & 543 & 346 & 197 & 0.363 & 511 & 456 & 55 & $0 \cdot 108$ & 0.654 & 0.346 & 0.69 & $0 \cdot 70$ \\
\hline
\end{tabular}

\section{TABLE II}

COMPARISONS BY $\chi^{2}$ (FOR $1 \mathrm{df}$ ) OF Xg GROUPS OF SAMPLES FROM FOUR MAIN AREAS

(The observed numbers on which the calculations are based are given in the last 4 rows of Table $I$ )

\begin{tabular}{|c|c|c|c|c|c|c|}
\hline & \multicolumn{3}{|c|}{ Males } & \multicolumn{3}{|c|}{ Females } \\
\hline & $\begin{array}{l}\text { Mainland } \\
\text { of } \\
\text { N. Europe }\end{array}$ & $\begin{array}{l}\text { Scandinavia } \\
\text { (excluding } \\
\text { Finland) }\end{array}$ & N. America & $\begin{array}{c}\text { Mainland } \\
\text { of } \\
\text { N. Europe }\end{array}$ & $\begin{array}{l}\text { Scandinavia } \\
\text { (excluding } \\
\text { Finland) }\end{array}$ & N. America \\
\hline \multirow{2}{*}{$\begin{array}{l}\text { Britain } \\
\text { N. America } \\
\text { Scandinavia (excluding } \\
\text { Finland) }\end{array}$} & $\begin{array}{l}0.99 \\
0.85\end{array}$ & $\begin{array}{l}1.99 \\
1.77\end{array}$ & 0.70 & $\begin{array}{l}0.50 \\
0.44\end{array}$ & $\begin{array}{l}8.38 \\
1.22\end{array}$ & $2 \cdot 06$ \\
\hline & 0.30 & & & $4 \cdot 32$ & & \\
\hline
\end{tabular}

\section{Families}

From the gene and phenotype frequencies may be calculated the expected frequencies of the 4 mating types in the population being dealt with, and also the expected incidence of the $\mathrm{Xg}$ groups in their offspring. Table III gives the formulae for families in which both parents have been tested, and also those for families in which only one parent has been tested. These formulae have been applied, in Tables IV and V, to the analysis of the various categories of families.

Analysis, row by row, using the local frequencies did not expose any tendencies not shown by applying the grand total frequencies which, for simplicity, alone are used in Tables IV and V. On the whole, the fit between the observed and expected distribution of mating types and offspring therefrom is good. The only significant departure is that too high a proportion of sons of the $\mathbf{X g}(\mathrm{a}+)$ mothers of Table $\mathrm{V}$ are $\mathrm{Xg}(\mathrm{a}-), \chi^{2}$ for $1 \mathrm{df}$ being 6.3. This excess was carried over from the 1966 account (Noades et al), where a probable reason was given; however, as the families tested since 1966 do not show the disturbance it need not be discussed again.

An excess of sons over daughters is often notable: this is due to selection of families with sons for the $\mathrm{X}$-linkage work. On the other hand, there was sometimes selection for daughters in families in which only the father had been grouped (Table V): 
TABLE III

EXPECTED DISTRIBUTION OF Xg GROUPS IN PARENTS AND OFFSPRING (From Noades et al, 1966)

\begin{tabular}{|c|c|c|c|c|c|c|c|c|c|}
\hline \multicolumn{4}{|c|}{ Mating } & \multicolumn{6}{|c|}{ Proportion of Xg Groups: } \\
\hline \multirow{2}{*}{ Total } & \multicolumn{2}{|c|}{ Type } & \multirow{2}{*}{ Frequency } & \multicolumn{3}{|c|}{ In Sons } & \multicolumn{3}{|c|}{ In Daughters } \\
\hline & Father & Mother & & Obs. Total & $\mathbf{X g}(\mathbf{a}+)$ & $\mathbf{X g}(\mathbf{a}-)$ & Obs. Total & $\mathrm{Xg}(\mathrm{a}+)$ & $\mathrm{Xg}(\mathrm{a}-)$ \\
\hline $\mathbf{p}_{\mathbf{n}}$ & $\begin{array}{l}\mathbf{X g}(\mathbf{a}+) \\
\mathbf{X} \mathbf{g}(\mathbf{a}+) \\
\mathbf{X} \mathbf{g}(\mathbf{a}-) \\
\mathbf{X} \mathbf{g}(\mathbf{a}-)\end{array}$ & $\begin{array}{l}\mathbf{X} \mathbf{g}(\mathbf{a}+) \\
\mathbf{X} \mathbf{g}(\mathbf{a}-) \\
\mathbf{X} \mathbf{g}(\mathbf{a}+) \\
\mathbf{X g}(\mathbf{a}-)\end{array}$ & 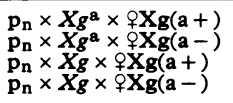 & $\begin{array}{l}\mathrm{s}_{1} \\
\mathrm{~s}_{2} \\
\mathrm{~s}_{3} \\
\mathrm{~s}_{4}\end{array}$ & $\begin{array}{r}s_{1} \times(a) \\
\text { None } \\
s_{3} \times(a) \\
\text { None }\end{array}$ & $\begin{array}{c}\mathbf{s}_{1} \times(b) \\
\text { All } \\
s_{3} \times(b) \\
\text { All }\end{array}$ & $\begin{array}{l}d_{1} \\
d_{2} \\
d_{3} \\
d_{4}\end{array}$ & $\begin{array}{c}\text { All } \\
\text { All } \\
\mathrm{d}_{3} \times(\mathrm{a}) \\
\text { None }\end{array}$ & $\begin{array}{c}\text { None } \\
\text { None } \\
d_{3} \times(b) \\
\text { All }\end{array}$ \\
\hline $\begin{array}{l}p_{1} \\
p_{2}\end{array}$ & $\begin{array}{c}\mathbf{X g}(\mathbf{a}+) \\
\mathbf{X g}(\mathbf{a}-) \\
? \\
?\end{array}$ & $\begin{array}{c}\stackrel{?}{?} \\
\mathbf{X g}(\mathbf{a}+) \\
\mathbf{X} \mathbf{g}(\mathbf{a}-)\end{array}$ & 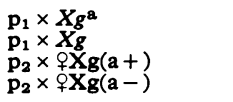 & $\begin{array}{l}\mathbf{s}_{5} \\
\mathbf{s}_{\mathbf{8}} \\
\mathbf{s}_{7} \\
\mathbf{s}_{\mathbf{8}}\end{array}$ & $\begin{array}{l}\mathrm{s}_{5} \times X g^{\mathrm{a}} \\
\mathrm{s}_{6} \times X g^{\mathrm{a}} \\
\mathrm{s}_{7} \times(\mathrm{a}) \\
\text { None }\end{array}$ & $\begin{array}{l}\mathrm{s}_{5} \times X g \\
\mathrm{~s}_{6} \times X g \\
\mathrm{~s}_{7} \times(\mathrm{b}) \\
\quad \text { All }\end{array}$ & $\begin{array}{l}d_{5} \\
d_{6} \\
d_{7} \\
d_{8}\end{array}$ & $\begin{aligned} & \text { All } \\
& d_{6} \times X g^{a} \\
& d_{7} \times(c) \\
& d_{8} \times X g^{a}\end{aligned}$ & $\begin{array}{c}\text { None } \\
\mathrm{d}_{6} \times X g \\
\mathrm{~d}_{7} \times(\mathrm{d}) \\
\mathrm{d}_{8} \times X g\end{array}$ \\
\hline
\end{tabular}

$X g^{a}$ and $\mathrm{Xg}=$ the gene frequencies in the appropriate population. $\quad+\mathrm{Xg}(\mathrm{a}+)$ and $\$ \mathrm{Xg}(\mathrm{a}-)=$ the calculated frequency of the two phenotypes in the females of the appropriate population.
(a) $=\frac{X g^{\mathbf{a}}}{\mathbf{q} \mathbf{X g}(\mathrm{a}+)}$
(b) $=1-$ (a)
(c) $=X_{g^{a}}+(b)$
(d) $=1-(c)$

$p_{n}=$ total number of families with both parents grouped; $p_{1}=$ mother not grouped; $p_{2}=$ father not grouped.

TABLE IV

Xg GROUPS OF 1348 FAMILIES OF NORTHERN EUROPEAN EXTRACTION WITH 3272 CHILDREN

(The expectations are based on the gene frequencies $X g^{a}=0.659$ and $X g=0.341$ )

\begin{tabular}{|c|c|c|c|c|c|c|c|c|}
\hline \multirow{3}{*}{ Matings } & \multirow{3}{*}{ No. } & \multicolumn{7}{|c|}{ Offspring } \\
\hline & & \multicolumn{3}{|c|}{ Sons } & \multicolumn{3}{|c|}{ Daughters } & \multirow{2}{*}{$\begin{array}{c}\text { Total } \\
\text { Children }\end{array}$} \\
\hline & & Total & $\mathbf{X g}(\mathbf{a}+)$ & $\mathbf{X g}(\mathbf{a}-)$ & Total & $\mathbf{X g}(\mathbf{a}+)$ & $\mathbf{X g}(\mathbf{a}-)$ & \\
\hline $\begin{array}{l}X g(a+) \text { father } \times X g(a+) \text { mother } \\
\text { England and Scotland } \\
\text { North America } \\
\text { Scandinavia (excluding Finland) } \\
\text { Finland } \\
\text { Netherlands } \\
\text { Rest of N. Europe }\end{array}$ & $\begin{array}{r}456 \\
96 \\
31 \\
88 \\
63 \\
57\end{array}$ & $\begin{array}{r}500 \\
169 \\
43 \\
156 \\
119 \\
81\end{array}$ & $\begin{array}{r}372 \\
124 \\
27 \\
135 \\
93 \\
61\end{array}$ & $\begin{array}{r}128 \\
45 \\
16 \\
21 \\
26 \\
20\end{array}$ & $\begin{array}{r}462 \\
122 \\
33 \\
105 \\
107 \\
54\end{array}$ & $\begin{array}{c}459 \\
122 \\
33 \\
105 \\
107 \\
54\end{array}$ & $\begin{array}{l}3^{*} \\
0 \\
0 \\
0 \\
0 \\
0\end{array}$ & $\begin{array}{r}962 \\
291 \\
76 \\
261 \\
226 \\
135\end{array}$ \\
\hline $\begin{array}{r}\text { Total } \\
\text { Expected } \\
\end{array}$ & $\begin{array}{l}791 \\
785 \cdot 3 \\
\end{array}$ & 1068 & $\begin{array}{l}812 \\
795 \cdot 7 \\
\end{array}$ & $\begin{array}{l}256 \\
272 \cdot 3 \\
\end{array}$ & 883 & $\begin{array}{l}880 \\
883 \cdot 0 \\
\end{array}$ & 3 & 1951 \\
\hline $\begin{array}{l}X g(a+) \text { father } \times X g(a-) \text { mother } \\
\text { England and Scotland } \\
\text { North America } \\
\text { Scandinavia (excluding Finland) } \\
\text { Finland } \\
\text { Netherlands } \\
\text { Rest of N. Europe } \\
\end{array}$ & $\begin{array}{l}46 \\
10 \\
10 \\
16 \\
15 \\
10\end{array}$ & $\begin{array}{l}51 \\
16 \\
16 \\
23 \\
24 \\
12 \\
\end{array}$ & $\begin{array}{l}7^{*} \\
0 \\
0 \\
0 \\
0 \\
0 \\
\end{array}$ & $\begin{array}{l}44 \\
16 \\
16 \\
23 \\
24 \\
12\end{array}$ & $\begin{array}{r}40 \\
8 \\
12 \\
19 \\
19 \\
13\end{array}$ & $\begin{array}{r}39 \\
8 \\
12 \\
19 \\
19 \\
13 \\
\end{array}$ & $\begin{array}{l}1^{*} \\
0 \\
0 \\
0 \\
0 \\
0 \\
\end{array}$ & $\begin{array}{l}91 \\
24 \\
28 \\
42 \\
43 \\
25\end{array}$ \\
\hline $\begin{array}{r}\text { Total } \\
\text { Expected } \\
\end{array}$ & $\begin{array}{l}107 \\
103 \cdot 1 \\
\end{array}$ & 142 & 7 & $\begin{array}{l}135 \\
142 \cdot 0 \\
\end{array}$ & 111 & $\begin{array}{l}110 \\
111 \cdot 0\end{array}$ & 1 & 253 \\
\hline $\begin{array}{l}X g(a-) \text { father } \times X g(a+) \text { mother } \\
\text { England and Scotland } \\
\text { North America } \\
\text { Scandinavia (excluding Finland) } \\
\text { Finland } \\
\text { Netherlands } \\
\text { Rest of N. Europe } \\
\end{array}$ & $\begin{array}{r}235 \\
46 \\
14 \\
39 \\
28 \\
30 \\
\end{array}$ & $\begin{array}{r}260 \\
78 \\
13 \\
56 \\
50 \\
34 \\
\end{array}$ & $\begin{array}{r}186 \\
50 \\
11 \\
43 \\
44 \\
19 \\
\end{array}$ & $\begin{array}{r}74 \\
28 \\
2 \\
13 \\
6 \\
15 \\
\end{array}$ & $\begin{array}{r}228 \\
55 \\
9 \\
46 \\
52 \\
41\end{array}$ & $\begin{array}{r}168 \\
37 \\
7 \\
37 \\
42 \\
24 \\
\end{array}$ & $\begin{array}{r}60 \\
18 \\
2 \\
9 \\
10 \\
17\end{array}$ & $\begin{array}{r}488 \\
133 \\
22 \\
102 \\
102 \\
75\end{array}$ \\
\hline $\begin{array}{r}\text { Total } \\
\text { Expected }\end{array}$ & $\begin{array}{l}392 \\
406 \cdot 3 \\
\end{array}$ & 491 & $\begin{array}{l}353 \\
365.8 \\
\end{array}$ & $\begin{array}{l}138 \\
125 \cdot 2 \\
\end{array}$ & 431 & $\begin{array}{l}315 \\
321 \cdot 1 \\
\end{array}$ & $\begin{array}{l}116 \\
109 \cdot 9 \\
\end{array}$ & 922 \\
\hline $\begin{array}{l}X g(a-) \text { father } \times X g(a-) \text { mother } \\
\text { England and Scotland } \\
\text { North America } \\
\text { Scandinavia (excluding Finland) } \\
\text { Finland } \\
\text { Netherlands } \\
\text { Rest of N. Europe } \\
\end{array}$ & $\begin{array}{r}24 \\
9 \\
6 \\
9 \\
5 \\
5 \\
\end{array}$ & $\begin{array}{r}23 \\
12 \\
9 \\
16 \\
9 \\
8 \\
\end{array}$ & $\begin{array}{l}0 \\
0 \\
0 \\
0 \\
0 \\
0 \\
\end{array}$ & $\begin{array}{r}23 \\
12 \\
9 \\
16 \\
9 \\
8 \\
\end{array}$ & $\begin{array}{r}22 \\
13 \\
11 \\
8 \\
4 \\
11 \\
\end{array}$ & $\begin{array}{l}0 \\
0 \\
0 \\
0 \\
0 \\
0\end{array}$ & $\begin{array}{r}22 \\
13 \\
11 \\
8 \\
4 \\
11\end{array}$ & $\begin{array}{l}45 \\
25 \\
20 \\
24 \\
13 \\
19\end{array}$ \\
\hline $\begin{array}{r}\text { Total } \\
\text { Expected }\end{array}$ & $\begin{array}{l}58 \\
53 \cdot 3 \\
\end{array}$ & 77 & 0 & $\begin{array}{l}77 \\
77 \cdot 0 \\
\end{array}$ & 69 & 0 & $\begin{array}{l}69 \\
69 \cdot 0 \\
\end{array}$ & 146 \\
\hline Grand total & 1348 & 1778 & & & 1494 & & & 3272 \\
\hline
\end{tabular}

* Exeeptional children, see text. 
TABLE V

X3 GROUPS OF 1192 PARENTS AND 2552 CHILDREN OF NORTHERN EUROPEAN EXTRACTION (ONE PARENT NOT TESTED)

(The expectations are based on the gene frequencies $X g^{\mathrm{a}}=0.659$ and $X g=0.341$ )

\begin{tabular}{|c|c|c|c|c|c|c|c|c|}
\hline \multirow{3}{*}{ Matings } & \multirow{3}{*}{ No. } & \multicolumn{6}{|c|}{ Offspring } & \multirow{3}{*}{$\begin{array}{c}\text { Total } \\
\text { Children }\end{array}$} \\
\hline & & \multicolumn{3}{|c|}{ Sons } & \multicolumn{3}{|c|}{ Daughters } & \\
\hline & & Total & $\mathbf{X g}(\mathbf{a}+)$ & $\mathbf{X g}(\mathbf{a}-)$ & Total & $\mathbf{X g}(\mathbf{a}+)$ & $\mathbf{X g}(\mathbf{a}-)$ & \\
\hline $\begin{array}{l}X g(a+) \text { father, mother not tested } \\
\text { England and Scotland } \\
\text { North America } \\
\text { Scandinavia (excluding Finland) } \\
\text { Finland } \\
\text { Netherlands } \\
\text { Rest of N. Europe }\end{array}$ & $\begin{array}{r}80 \\
16 \\
7 \\
24 \\
13 \\
8\end{array}$ & $\begin{array}{r}42 \\
5 \\
5 \\
31 \\
28 \\
8\end{array}$ & $\begin{array}{r}27 \\
4 \\
4 \\
26 \\
24 \\
5\end{array}$ & $\begin{array}{r}15 \\
1 \\
1 \\
5 \\
4 \\
3\end{array}$ & $\begin{array}{r}102 \\
18 \\
7 \\
29 \\
25 \\
7\end{array}$ & $\begin{array}{r}102 \\
18 \\
7 \\
29 \\
25 \\
7\end{array}$ & $\begin{array}{l}0 \\
0 \\
0 \\
0 \\
0 \\
0\end{array}$ & $\begin{array}{r}144 \\
23 \\
12 \\
60 \\
53 \\
15\end{array}$ \\
\hline $\begin{array}{r}\text { Total } \\
\text { Expected }\end{array}$ & $\begin{array}{l}148 \\
147 \cdot 0\end{array}$ & 119 & $\begin{array}{l}90 \\
78 \cdot 4\end{array}$ & $\begin{array}{l}29 \\
40 \cdot 6\end{array}$ & 188 & $\begin{array}{l}188 \\
188 \cdot 0\end{array}$ & 0 & 307 \\
\hline $\begin{array}{l}X g(a-) \text { father, mother not tested } \\
\text { England and Scotland } \\
\text { North America } \\
\text { Scandinavia (excluding Finland) } \\
\text { Finland } \\
\text { Netherlands } \\
\text { Rest of N. Europe }\end{array}$ & $\begin{array}{r}33 \\
21 \\
2 \\
6 \\
8 \\
5\end{array}$ & $\begin{array}{r}16 \\
18 \\
0 \\
2 \\
6 \\
7\end{array}$ & $\begin{array}{r}11 \\
7 \\
0 \\
1 \\
6 \\
4\end{array}$ & $\begin{array}{r}5 \\
11 \\
0 \\
1 \\
0 \\
3\end{array}$ & $\begin{array}{r}37 \\
30 \\
3 \\
5 \\
16 \\
7\end{array}$ & $\begin{array}{r}20 \\
24 \\
3 \\
4 \\
7 \\
4\end{array}$ & $\begin{array}{r}17 \\
6 \\
0 \\
1 \\
9 \\
3\end{array}$ & $\begin{array}{r}53 \\
48 \\
3 \\
7 \\
22 \\
14\end{array}$ \\
\hline $\begin{array}{r}\text { Total } \\
\text { Expected }\end{array}$ & $\begin{array}{l}75 \\
76 \cdot 0 \\
\end{array}$ & 49 & $\begin{array}{l}29 \\
32 \cdot 3\end{array}$ & $\begin{array}{l}20 \\
16 \cdot 7\end{array}$ & 98 & $\begin{array}{l}62 \\
64 \cdot 6\end{array}$ & $\begin{array}{l}36 \\
33 \cdot 4\end{array}$ & 147 \\
\hline $\begin{array}{l}\text { Father not tested, Xg(a+) mother } \\
\text { England and Scotland } \\
\text { North America } \\
\text { Scandinavia (excluding Finland) } \\
\text { Finland } \\
\text { Netherlands } \\
\text { Rest of N. Europe }\end{array}$ & $\begin{array}{r}398 \\
204 \\
27 \\
88 \\
72 \\
65 \\
\end{array}$ & $\begin{array}{r}509 \\
359 \\
18 \\
130 \\
106 \\
93\end{array}$ & $\begin{array}{r}377 \\
242 \\
10 \\
98 \\
80 \\
60 \\
\end{array}$ & $\begin{array}{r}132 \\
117 \\
8 \\
32 \\
26 \\
33\end{array}$ & $\begin{array}{r}293 \\
142 \\
22 \\
77 \\
65 \\
59\end{array}$ & $\begin{array}{r}273 \\
130 \\
19 \\
68 \\
58 \\
46\end{array}$ & $\begin{array}{r}20 \\
12 \\
3 \\
9 \\
7 \\
13\end{array}$ & $\begin{array}{r}802 \\
501 \\
40 \\
207 \\
171 \\
152\end{array}$ \\
\hline $\begin{array}{r}\text { Total } \\
\text { Expected }\end{array}$ & $\begin{array}{l}854 \\
856 \cdot 6\end{array}$ & 1215 & $\begin{array}{l}867 \\
905 \cdot 2\end{array}$ & $\begin{array}{l}348 \\
309 \cdot 8\end{array}$ & 658 & $\begin{array}{l}594 \\
601 \cdot 4 \\
\end{array}$ & $\begin{array}{l}64 \\
56 \cdot 6\end{array}$ & 1873 \\
\hline $\begin{array}{l}\text { Father not tested, } X g(a-) \text { mother } \\
\text { England and Scotland } \\
\text { North America } \\
\text { Scandinavia (excluding Finland) } \\
\text { Finland } \\
\text { Netherlands } \\
\text { Rest of N. Europe }\end{array}$ & $\begin{array}{r}44 \\
36 \\
6 \\
14 \\
5 \\
10\end{array}$ & $\begin{array}{r}46 \\
41 \\
5 \\
20 \\
5 \\
12\end{array}$ & $\begin{array}{l}0 \\
0 \\
0 \\
0 \\
0 \\
0 \\
\end{array}$ & $\begin{array}{r}46 \\
41 \\
5 \\
20 \\
5 \\
12 \\
\end{array}$ & $\begin{array}{r}31 \\
29 \\
2 \\
16 \\
8 \\
10 \\
\end{array}$ & $\begin{array}{r}20 \\
15 \\
1 \\
9 \\
7 \\
9 \\
\end{array}$ & $\begin{array}{r}11 \\
14 \\
1 \\
7 \\
1 \\
1 \\
\end{array}$ & $\begin{array}{r}77 \\
70 \\
7 \\
36 \\
13 \\
22 \\
\end{array}$ \\
\hline $\begin{array}{r}\text { Total } \\
\text { Expected }\end{array}$ & $\begin{array}{l}115 \\
112 \cdot 4\end{array}$ & 129 & 0 & $\begin{array}{l}129 \\
129 \cdot 0\end{array}$ & 96 & $\begin{array}{l}61 \\
63 \cdot 3 \\
\end{array}$ & $\begin{array}{l}35 \\
32 \cdot 7 \\
\end{array}$ & 225 \\
\hline Grand total & 1192 & 1512 & & & 1040 & & & 2552 \\
\hline
\end{tabular}

this was because maternal grandfathers were specially sought, in the hope of getting threegeneration linkage information. When kindreds were tested, each separate family unit within the kindred was entered in the tables.

Exceptional Children. In Table IV there are 11 children who appear to break the rules of Xlinked inheritance, all 11 are in the England plus Scotland division. No exceptions are disclosed in Table V. Exceptions could be explained by illegitimacy, but all the families in Tables IV and V were tested for a variety of other groups besides $\mathrm{Xg}$ and any members shown to be illegitimate by these other groups were omitted from the counts. Of course, 45, X daughters of $\mathrm{Xg}(\mathrm{a}+)$ fathers are often
$\mathrm{Xg}(\mathrm{a}-)$ and $47, \mathrm{XXY}$ sons of $\mathrm{Xg}(\mathrm{a}-)$ mothers are sometimes $\mathrm{Xg}(\mathrm{a}+)$, but families with such $\mathrm{X}$ chromosome abnormalities (Sanger, Tippett, and Gavin, 1971) are excluded from these tables.

$\mathbf{X g}(\mathbf{a}-)$ Daughters of $\mathbf{X g}(\mathbf{a}+)$ Fathers. One $\mathrm{Xg}(\mathrm{a}-)$ daughter (Mary Ro. PRU 1492/4036) from the mating $\mathrm{Xg}(\mathrm{a}+) \times \mathrm{Xg}(\mathrm{a}+)$ was a patient of Professor Polani. She was trisomic for one of the $\mathrm{D}$ group chromosomes and died at birth. The sample of blood was 1 week old before the $\mathrm{Xg}$ tests were done, but it looked in good condition and the other blood group reactions appeared to be normal. Her parents were tested some time later, so the baby was not recognized as exceptional in her $\mathrm{Xg}$ group until it was too late to confirm the $\mathrm{Xg}(\mathrm{a}-)$ re- 
action by absorption tests. The other blood groups afforded no reason to doubt the paternity of the baby.

A second $\mathrm{Xg}(\mathrm{a}-)$ girl (K.M.) from the mating $\mathrm{Xg}(\mathrm{a}+) \times \mathrm{Xg}(\mathrm{a}+)$ was the 7-year-old sister of a patient of Dr J. D. Allan. Her autosomal groups were compatible with those of her parents but a slightly unusual genotypic interpretation had to be invoked.

A third $\mathrm{Xg}(\mathrm{a}-)$ girl (B.W.) from the mating $\mathrm{Xg}(\mathrm{a}+) \times \mathrm{Xg}(\mathrm{a}+)$ was a patient of Professor J. $\mathrm{H}$. Edwards. She was aged nearly 3 . The sample of blood was rather small so only a limited number of autosomal groups could be done, but as far as they went they were compatible with those of her parents.

The Xg(a-) girl (Carol Ow. PRU 1428/3806) from the mating $\mathrm{Xg}(\mathrm{a}+) \times \mathrm{Xg}(\mathrm{a}-)$ was a patient of Professor Polani: she was trisomic for one of the E group of chromosomes and died at the age of 4 weeks. An elder sister is $\mathrm{Xg}(\mathrm{a}+)$ and a brother is $\mathrm{Xg}(\mathrm{a}-)$. The $\mathrm{Xg}(\mathrm{a}-)$ reaction of the baby was confirmed by absorption tests and the reactions of the parents were confirmed on second samples of their blood. Paternity in this family could be established, for both the father and the baby were found by Professor $\mathrm{H}$. Lehmann to have a peculiar type of haemoglobin.

It should be noted, when considering the two exceptional baby girls who were trisomic, that the antigen $\mathrm{Xg}^{\mathrm{a}}$ is not always developed fully before birth (Toivanen and Hirvonen, 1969) and that we have evidence that the $\mathrm{Xg}^{\mathrm{a}}$ antigen of babies with the trisomies of Down, Edwards, and Patau tends to be weaker than that of normal babies.

It seems to us that, for one reason or another, the 4 exceptions above do not carry the weight of those about to be described.

$\mathbf{X g}(\mathbf{a}+)$ Sons of $\mathbf{X g}(\mathbf{a}-)$ Mothers. The 7 such sons in Table IV belong to 3 families, Je., Bu., and Wa., which have been recorded elsewhere (Sanger et al, 1964 and 1968):

fe. family: father $\mathrm{Xg}(\mathrm{a}+)$, mother $\mathrm{Xg}(\mathrm{a}-)$, both of two sons $\mathrm{Xg}(\mathrm{a}+)$.

Bu. family: father $\mathrm{Xg}(\mathrm{a}+)$, mother $\mathrm{Xg}(\mathrm{a}-)$, all three sons $\mathbf{X g}(\mathrm{a}+)$.

Wa. family: father $\mathrm{Xg}(\mathrm{a}+)$, mother $\mathrm{Xg}(\mathrm{a}-)$, both of two sons $\mathrm{Xg}(\mathrm{a}+)$.

A possible explanation which we had come to favour was that in the ancestry of the fathers of the $\mathrm{Xg}(\mathrm{a}+)$ boys a small portion of an $\mathrm{X}$, involving the $X g$ locus (occupied by the allele $X g^{a}$ ), had become translocated on to a $\mathrm{Y}$, or even on to an autosome. However, when family Wa. was tested the groups of three generations excluded, in their case at any rate, a translocation on to $\mathrm{a} Y$.

A further family (Buckton et al, 1971), not included in this series of families because it was tested after 23 December 1969 (and which would not have qualified anyhow because it involved a sex chromosome abnormality), perfectly explains itself and offers a possible solution to the earlier families. The peripheral blood of a mother was found at the MRC Clinical and Population Cytogenetics Unit to be mosaic $45, \mathrm{X} / 46, \mathrm{XX}$, the two cell lines being in the approximate proportion of 1 to 2 . The mother and her husband were phenotypically $\mathrm{Xg}(\mathrm{a}-)$ but one son and one daughter were $\mathbf{X g}(\mathrm{a}+)$. It was assumed, because of her fertility, that her gonads were, at least in part, $46, \mathrm{XX}$, and, because of the exceptional $\mathrm{Xg}$ inheritance that her genotype must be $X g^{a} X g$ but that her red cells were derived from a predominantly $45, \mathrm{X}$ line; the latter presumption was supported when the karyotype of her marrow showed about $90 \%$ of the cells to be $45, \mathrm{X}$.

Trying to put these $\mathrm{Xg}(\mathrm{a}+)$ sons of $\mathrm{Xg}(\mathrm{a}-)$ mothers into their proper perspective Sanger et al (1964) asked the following questions:

(1) How uncommon is it for $\mathrm{Xg}(\mathrm{a}+)$ sons to have $\mathrm{Xg}(\mathrm{a}-)$ mothers? The answer, brought up to 23 December 1969, is that in all the families we have tested-British, North American, northern European, Sardinian, Israeli, Negro, Chinese, etc-3231 $\mathrm{Xg}(\mathrm{a}+)$ sons have sprung from 1897 mothers, 1894 of whom are $\mathrm{Xg}(\mathrm{a}+)$ and 3 (Mrs Je., Mrs Bu., and Mrs Wa.) are $\mathrm{Xg}(\mathrm{a}-)$.

(2) How uncommon is it for $\mathrm{Xg}(\mathrm{a}-)$ mothers to have $\mathrm{Xg}(\mathrm{a}+)$ sons? The December 1969 count shows that $303 \mathrm{Xg}(\mathrm{a}-)$ mothers of sons have been tested: 300 of them have $523 \mathrm{Xg}(\mathrm{a}-)$ sons and 3 (Mrs Je., Mrs Bu., and Mrs Wa.) have $7 \mathrm{Xg}(\mathrm{a}+$ ) sons.

It should be added that Chown et al (1964) in a series of 294 white families, mainly Canadian, also found one in which an $\mathrm{Xg}(\mathrm{a}-)$ mother had an $\mathrm{Xg}(\mathrm{a}+)$ son.

$\mathrm{Xg}$ and Lyonization. The existence of these $\mathrm{Xg}(\mathrm{a}+)$ sons of $\mathrm{Xg}(\mathrm{a}-)$ mothers could be attributed to Lyonization, provided the $X g$ locus when carried on a structurally normal $\mathrm{X}$ is subject to inactivation, and provided that inactivation happens at such an early stage of embryonic life that there are very few ancestral cells of the erythroid series.

Our present opinion is that $\mathrm{Xg}$ locus of a structurally normal $\mathbf{X}$ is not involved in inactivation (Gorman et al, 1963; Fialkow, 1970; Fialkow et al, 1970; Lawler and Sanger, 1970). The only 
evidence in favour of its inactivation (Lee et al, 1968) could not be confirmed (Weatherall et al, 1970).

Gandini and his collaborators (1968) from a study of women heterozygous at the locus for glucose-6phosphate dehydrogenase estimated that at the time of inactivation the primordial cells destined to form the erythroid series number 8 or less.

\section{TABLE VI}

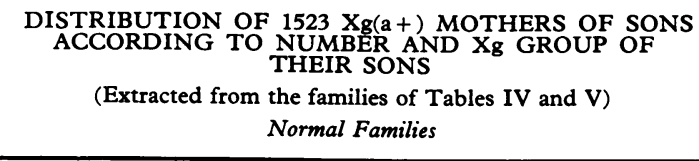

\begin{tabular}{|c|c|c|c|c|c|c|c|c|c|}
\hline \multicolumn{10}{|c|}{535 Mothers with: } \\
\hline \multirow{2}{*}{$\begin{array}{c}\text { Sons } \\
\mathbf{X g}(\mathbf{a}-)\end{array}$} & \multicolumn{9}{|c|}{ Sons $\mathrm{Xg}(\mathrm{a}+)$} \\
\hline & 0 & 1 & 2 & 3 & 4 & 5 & 6 & 7 & 8 \\
\hline 0 & & $\begin{array}{l}253 \\
258 \cdot 7\end{array}$ & $\begin{array}{l}72 \\
81 \cdot 6\end{array}$ & $\begin{array}{l}28 \\
23 \cdot 3\end{array}$ & $\begin{array}{l}5 \\
4 \cdot 2\end{array}$ & 2 & & 1 & \\
\hline 1 & $\begin{array}{l}94 \\
88 \cdot 3\end{array}$ & $\begin{array}{l}45 \\
33 \cdot 6\end{array}$ & $\begin{array}{l}4 \\
8 \cdot 0\end{array}$ & $\begin{array}{l}2 \\
1 \cdot 0\end{array}$ & & & & & \\
\hline 2 & $\begin{array}{l}15 \\
16 \cdot 8\end{array}$ & $\begin{array}{l}9 \\
8 \cdot 0\end{array}$ & $\frac{1}{1 \cdot 5}$ & & & & & & \\
\hline 3 & $\frac{1}{2 \cdot 7}$ & $\begin{array}{l}0 \\
1 \cdot 0\end{array}$ & 1 & & & & & & \\
\hline 4 & $\begin{array}{l}0 \\
0.3\end{array}$ & 1 & & & & & 1 & & \\
\hline 5 & & & & & & & & & \\
\hline
\end{tabular}

$X$-Linkage Families

\begin{tabular}{|c|c|c|c|c|c|c|c|c|c|}
\hline \multicolumn{10}{|c|}{988 Mothers with: } \\
\hline \multirow{2}{*}{$\begin{array}{c}\text { Sons } \\
\mathbf{X g}(\mathbf{a}-)\end{array}$} & \multicolumn{9}{|c|}{ Sons $\mathbf{X g}(\mathbf{a}+)$} \\
\hline & 0 & 1 & 2 & 3 & 4 & 5 & 6 & 7 & 8 \\
\hline 0 & & $\begin{array}{l}358 \\
348 \cdot 9\end{array}$ & $\begin{array}{l}161 \\
178 \cdot 7\end{array}$ & $\begin{array}{l}73 \\
73 \cdot 8\end{array}$ & $\begin{array}{l}28 \\
29 \cdot 8\end{array}$ & $\begin{array}{l}14 \\
12 \cdot 7\end{array}$ & 4 & 1 & 2 \\
\hline 1 & $\begin{array}{l}110 \\
119 \cdot 1\end{array}$ & $\begin{array}{l}67 \\
73 \cdot 6\end{array}$ & $\begin{array}{l}31 \\
25 \cdot 4\end{array}$ & $\begin{array}{l}7 \\
7 \cdot 2\end{array}$ & $\begin{array}{l}1 \\
2 \cdot 0\end{array}$ & 1 & & 2 & \\
\hline 2 & $\begin{array}{l}61 \\
36 \cdot 8\end{array}$ & $\begin{array}{l}21 \\
25 \cdot 4\end{array}$ & $\begin{array}{l}12 \\
10 \cdot 9\end{array}$ & $\begin{array}{l}7 \\
4 \cdot 0\end{array}$ & 1 & & & & \\
\hline 3 & $\begin{array}{l}8 \\
8 \cdot 5\end{array}$ & $\begin{array}{l}5 \\
7 \cdot 2\end{array}$ & $\begin{array}{l}2 \\
4 \cdot 0\end{array}$ & 1 & & & & & \\
\hline 4 & $\begin{array}{l}5 \\
1 \cdot 8\end{array}$ & $\begin{array}{l}0 \\
2 \cdot 0\end{array}$ & 1 & & & 1 & & & 1 \\
\hline 5 & $\begin{array}{l}1 \\
0.4\end{array}$ & & & 1 & & & & & \\
\hline
\end{tabular}

If, against the weight of other evidence, the $X g$ locus were subject to inactivation, and if the number of primordial erythroid cells were as few as 8 , then there should be a slight excess of $\mathrm{Xg}(\mathrm{a}-)$ amongst the 3271 females of Table I when analysed by the gene frequencies given by the 3513 males of that table. That there is a non-significant shortage of $\mathrm{Xg}(\mathrm{a}-)$ females (expected 386.0 , observed 371 ) brings no support for the inactivation of $\mathrm{Xg}$. If the number of primordial erythroid cells, at the time of inactivation, were as few as 4 the observed shortage of $\mathrm{Xg}(\mathrm{a}-)$ females would be highly significant evidence against $X g$ being involved.

Professor J. H. Edwards suggested we should make a count of $\mathrm{Xg}(\mathrm{a}+)$ mothers according to the number of their $\mathrm{Xg}(\mathrm{a}+)$ and $\mathrm{Xg}(\mathrm{a}-)$ sons, in the form shown in Table VI. If the $X g$ locus were subject to inactivation and if inactivation does happen at the very early stage ' 8 cells or less' of erythroid development then some discrepancies might emerge between the observed and expected contents of some of the boxes of such a table. A count was therefore made of sons of $\mathrm{Xg}(\mathrm{a}+)$ mothers in Tables IV and V of this paper and the fit between observed and expected was very close in all but two of the boxes. Clearly something was wrong with the two son families: much too often both sons were $\mathrm{Xg}(\mathrm{a}-$ ) (observed 76, expected $53 \cdot 6$ ) and somewhat too seldom both were $\mathrm{Xg}(\mathrm{a}+)$ (observed 233 , expected $260 \cdot 3$ ).

There were two classes of families in this first count: (1) 'normal' families involved in blood group problems unrelated to $\mathrm{Xg}$ and (2) families with $\mathrm{X}-8$ linked conditions and $\mathrm{Xg}$ grouped for $\mathrm{X}$-mapping purposes. When the two groups are separated, aso in Table VI, the excess of mothers with $\mathrm{Xg}(\mathrm{a}-)$. sons in the two son families is seen to be confined to class (2). We presume this must reflect the energetic pursual of relatives of mothers who had proved themselves heterozygous, $X g^{a} X g$, and therefore informative for X-linkage (Noades et al, 1966). We do not know why this presumed selection appears to affect only the two-son families.

Apparent exceptions to the dominant X-linked inheritance of the antigen $\mathrm{Xg}^{\mathrm{a}}$, when not due to frank X-chromosome aneuploidy, are rare and their causes unresolved.

\section{Summary}

The accounts of the Xg blood groups of white people of northern European ancestry tested at the MRC Blood Group Unit are brought up to 23 December 1969. The samples were sent from Britain, North America, Scandinavia, and from the mainland of northern Europe.

From 6784 unrelated people the calculated gene frequencies are: $X g^{\mathrm{a}} 0.659$ and $X g$ 0.341 which, curiously and conveniently, are exactly those of the last report, in 1966, when only 3418 of these people had been tested.

The gene frequencies are used to analyse the 
results of testing 2540 families of northern European ancestry with 5824 children, and the observed and calculated numbers fit well. Eleven of the children, belonging to 7 families, appear to break the rules of $\mathrm{X}$-linked inheritance, and possible explanations are discussed.

We thank the very many physicians who sent samples from the families here recorded. Many of the families have been published in separate papers dealing with the search for linkage between $\mathrm{Xg}$ and other $\mathrm{X}$-linked conditions.

Much involved in the $\mathrm{Xg}$ testing were past members of the Unit: Miss Jean Hamper, Miss Jean Noades, Mrs Ann Gooch, and Mrs Joan Whittaker.

Our thanks for magnificent gifts of anti-Xga and the rather special antiglobulin-serum it requires are expressed in another paper in this issue (p. 425).

\section{REFERENCES}

Buckton, K. E., Cunningham, C., Newton, M. S., O'Riordan, M. L., and Sanger, R. (1971). Anomalous Xg inheritance with a probable explanation. Lancet, 1, 371-373.

Chown, B., Lewis, M., and Kaita, H. (1964). The Xg blood group system: data on 294 white families, mainly Canadian. Canadian fournal of Genetics and Cytology, 6, 431-434.

Dewey, W. J. and Mann, J. D. (1967). Xg blood group frequencies in some further populations. Fournal of Medical Genetics, 4, 12-15.

Fialkow, P. J. (1970). X-chromosome inactivation and the Xg locus. American fournal of Human Genetics, 22, 460-463.

Fialkow, P. J., Lisker, R., Giblett, E. R. and Zavala, C. (1970). Xg locus: failure to detect inactivation in females with chronic myelocytic leukaemia. Nature, 226, 367-368.

Gandini, E., Gartler, S. M., Angioni, G., Argiolas, N., and Dell'Acqua, G. (1968). Developmental implications of multiple tissue studies in glucose-6-phosphate dehydrogenase-deficient heterozygotes. Proceedings of the National Academy of Sciences, 61, 945-948.

Gorman, J. G., Di Re, J., Treacy, A. M., and Cahan, A. (1963). The application of $-\mathrm{Xg}^{\mathrm{a}}$ antiserum to the question of red cell mosaicism in female heterozygotes. Fournal of Laboratory and Clinical Medicine, 61, 642-649.

Haldane, J. B. S. (1963). Tests for sex-linked inheritance on population samples. Annals of Human Genetics, 27, 107-111.

Lawler, S. D. and Sanger, R. (1970). Xg blood-groups and clonalorigin theory of chronic myeloid leukaemia. Lancet, 1, 584-585.

Lee, G. R., MacDiarmid, W. D., Cartwright, G. E., and Wintrobe M. M. (1968). Hereditary, X-linked, sideroachrestic anemia. The isolation of two erythrocyte populations differing in $\mathbf{X g}^{\mathrm{a}}$ blood type and porphyrin content. Blood, 32, 59-70.

Mann, J. D., Cahan, A., Gelb, A. G., Fisher, N., Hamper, J., Tippett, P., Sanger, R., and Race, R. R. (1962). A sex-linked blood group. Lancet, 1, 8-10.

Metaxas, M. N. and Metaxas-Bühler, M. (1970). An agglutinating example of anti- $\mathrm{Xg}^{\mathrm{a}}$ and $\mathrm{Xg}^{\mathrm{a}}$ frequencies in 558 Swiss blood donors. Vox Sanguinis, 19, 527-529.

Noades, J., Gavin, J., Tippett, P., Sanger, R., and Race, R. R (1966). The X-linked blood group system Xg. Tests on British, Northern American and Northern European unrelated people and families. Fournal of Medical Genetics, 3, 162-168.

Sanger, R., Race, R. R., Tippett, P., Gavin, J., Cleghorn, T. E., and Rogers, K. L. quoted by Race, R. R., and Sanger, R. (1968). Blood Groups in Man, 5th ed., p. 576. Blackwell Scientific Oxford.

Sanger, R., Race, R. R., Tippett, P., Gavin, J., Hardisty, R. M., and Dubowitz, V. (1964). Unexplained inheritance of the Xg groups in two familes. Lancet, 1, 955-956.

Sanger, R., Tippett, P., and Gavin, J. (1971). Xg groups and sex abnormalities in people of northern European ancestry. Fournal of Medical Genetics, 8, 417-426.

Toivanen, P. and Hirvonen, T. (1969). Fetal development of red cell antigens $\mathbf{K}, \mathbf{k}, \mathbf{L u}^{\mathrm{a}}, \mathbf{L u}^{\mathrm{b}}, \mathbf{F y}{ }^{\mathrm{a}}, \mathrm{Fy}^{\mathrm{b}}, \mathrm{Vel}$ and $\mathbf{X g}^{\mathrm{a}}$. Scandinavian fournal of Haematology, 6, 49-55.

Weatherall, D. J., Pembrey, M. E., Hall, E. G., Sanger, R., Tippett, P., and Gavin, J. (1970). Familial sideroblastic anaemia: problem of $\mathrm{Xg}$ and $\mathrm{X}$ chromosome inactivation. Lancet, 2, 744748. 